\title{
ANALISIS SISTEM INFORMASI AKUNTANSI PERSEDIAAN OBAT-OBATAN PADA RUMAH SAKIT AR BUNDA LUBUKLINGGAU
}

\author{
${ }^{1}$ Aulia Tri Rizky, ${ }^{2}$ Dewi Anggraini, ${ }^{3}$ Yuli Nurhayati \\ 1,2,3 Program Studi Akuntansi, Universitas Bina Insan, Lubuklinggau \\ E-mail : ${ }^{1}$ auliatririzky02@gmail.com, ${ }^{2}$ dewi_anggraini@univbinainsan.ac.id, \\ 3yulinurhayati@univbinainsan.ac.id
}

\begin{abstract}
ABSTRAK
Aktivitas operasional Rumah Sakit, obat merupakan persediaan yang frekuensi penggunaannya paling tinggi. Dalam menunjang pengelolaan persediaan obat yang efektif dan efiseien maka diperlukan Sistem Informasi Akuntansi Persediaan yang lebih aktual dan memadai. Tujuan dari penelitian ini adalah untuk mengetahui bagaimana sistem informasi akuntansi persediaan obat-obatan pada Rumah Sakit AR Bunda Lubuklinggau. Penelitian ini menggunakan metode kualitatif deskriptif. Sumber data yang digunakan yaitu data primer dan data sekunder. Teknik pengumpulan data menggunakan observasi, wawancara dan dokumentasi. Hasil penelitian menunjukkan bahwa Sistem Informasi Akuntansi Persediaan Obat-obatan pada Rumah Sakit AR Bunda Lubuklinggau sudah berjalan dengan baik tetapi masih terdapat beberapa kelemahan yaitu pada prosedur pengadaan obat-obatan, adanya perangkapan tugas Kepala Instalasi Farmasi serta kurang lengkapnya beberapa dokumen/formulir dan catatan akuntansi yang mendukung sistem informasi akuntansi persediaan.
\end{abstract}

Kata kunci : Sistem Informasi Akuntansi, Persediaan Obat

\begin{abstract}
The hospital operational activities, medical supplies have the most frequent usage. To support medical supplies management that is effective and efficient, the management needs accounting information system of inventory that is more actual and adequate. The purpose of this research is to found accounting information system of inventory in AR Bunda Hospital. This method of research is a qualitative study by using descriptive approach. The sources of the data are primary data and secondary data. There are three ways in technique for collecting the data, namely observation, interview, and documentation. The result of the study found that accounting information system of inventory in AR Bunda Hospital are going well, but the are some weakness such as medical supplies procedure, multiply task head of pharmacy installation, the lack of some documents/form and the accounting records to support accounting informaton system of inventory.
\end{abstract}

Keywords : Accounting Information system, Medical supplies 


\section{PENDAHULUAN}

Di era globalisasi ini, teknologi mengalami perkembangan yang cukup pesat. Peran teknologi menjadikan pengolahan informasi menjadi semakin mudah karena pengolahan sangat diperlukan agar informasi yang dihasilkan dapat bermanfaat bagi penggunanya. Seiring berkembangnya kemajuan teknlogi informasi dan komunikasi, persaingan bisnis dalam dunia industri semakin ketat. Jumlah perusahaan semakin banyak dan terus melakukan usaha dan strategi dalam mempertahankan bisnisnya. Kesuksesan perusahaan dalam mempertahankan bisnisnya tidak terlepas dari peran perusahaan tersebut dalam mengelola persediaan barang. Sistem informasi akuntansi merupakan hal yang diperlukan oleh suatu perusahaan dalam menangani kegiatan operasional untuk menghasilkan informasi-informasi akuntansi serta informasi lainnya yang berguna dalam pengambilan keputusan dan kebijakankebijakan lainnya.

Rumah sakit merupakan perusahaan berbentuk jasa yang bertujuan memberikan pelayanan kesehatan. Salah satu bentuk pelayanan yang ditawarkan Rumah Sakit adalah dengan memberikan obat-obatan sesuai dengan penyakit yang diderita pasien atau resep yang telah dianjurkan oleh dokter. Rumah Sakit AR Bunda Lubuklinggau merupakan salah satu Rumah Sakit Swasta yang berada di kota Lubuklingau. Rumah Sakit ini memiliki tingkat hunian dan angka kunjungan pasien yang cukup tinggi. Pasienpasien tersebut tentunya akan mendapatkan resep obat dari dokter untuk ditebus pada bagian farmasi Rumah Sakit.

Tingkat perputaran obat-obatan yang tinggi pada Rumah Sakit ini menyebabkan diperlukannya pengelolaan, pengawasan dan pengendalian yang terbaik terhadap persediaan obat-obatan. Tujuannya adalah untuk menjaga persediaan obat-obatan dari resiko kehilangan dan kerusakan, memeriksa ketelitian dan kebenaran data akuntansinya, meningkatkan efisiensi, menghindari terjadinya kesalahan-kesalahan dan penyimpangan-penyimpangan yang mungkin terjadi yang data merugikan rumah sakit, serta membantu menjaga dipenuhinya kebijakan manajemen yang lebih dulu ditetapkan.

Berdasarkan latar belakang diatas, maka peneliti tertarik untuk melakukan penelitian tentang Analisis Sistem Informasi Akuntansi Persediaan obat-obatan pada Rumah Sakit AR Bunda Lubuklinggau. Tujuan Penelitian dalam penelitian ini yaitu untuk mengetahui bagaimana Sistem Informasi Akuntansi Persediaan Obat-obatan pada Rumah Sakit AR Bunda Lubuklinggau.

\section{TINJAUAN PUSTAKA}

\subsection{Sistem Informasi}

Pada dasarnya sistem adalah suatu kerangka dari prosedur-prosedur yang saling berhubungan, yang disusun sesuai dengan skema yang menyeluruh. Untuk melaksanakan suatu kegiatan atau fungsi utama dari perusahaan yang dihasilkan oleh suatu proses tertentu bertujuan menyediakan informasi untuk membantu pengambilan keputusan manajemen, operasi perusahaan dari hari ke hari serta menyediakan informasi yang layak untuk pihak diluar perusahaan. Sistem adalah suatu jaringan prosedur yang dibuat menurut pola yang terpadu untuk melaksanakan kegiatan pokok perusahaan.[1]

\subsection{Sistem Informasi Akuntansi}

Sistem Informasi Akuntansi adalah suatu sistem yang terdiri dari berbagai formulir, catatan dan laporan yang telah disusun dan menghasilkan suatu informasi keuangan yang dibutuhkan oleh perusahaan. Sistem akuntansi adalah organisasi formulir, catatan dan laporan yang dikoordinasi sedemikian rupa untuk menyediakan informasi keuangan yang dibutuhkan oleh manajemen guna memudahkan pengelolaan perusahaan. [1] 


\subsection{Persediaan}

Persediaan adalah aset tersedia untuk dijual dalam kegiatan usaha biasa, dalam proses produksi untuk penjualan tersebut, atau dalam bentuk bahan atau perlengkapan untuk digunakan dalam proses produksi atau pemberian jasa [2]

\subsection{Sistem Informasi Akuntansi Persediaan}

Sistem Akuntansi Persediaan adalah sistem yang dirancang untuk menangani transaksi yang bersangkutan dengan mutasi persediaan yang disimpan di gudang [1]. Fungsi yang terkait dengan akuntansi persediaan adalah: a) Fungsi Gudang bertanggung jawab dalam penyimpanan barang persediaan; b) Fungsi Penjualan atau Pemakaian bertanggung jawab atas penjualan barang; c) Fungsi ini bertanggung jawab membeli persediaan yang hampir habis kepada pemasok; d) Fungsi ini bertanggung jawab untuk melakukan pemeriksaan terhadap jenis, mutu, dan kuantitas barang yang diterima dari pemasok guna menentukan dapat tidaknya barang tersebut diterima perusahaan; e) Fungsi Akuntansi berperan sebagai pencatat uang dan fungsi pencatat persediaan; f) Fungsi Perhitungan Fisik Persediaan [3].

Dokumen yang digunakan dalam sistem akuntansi persediaan adalah: a) Surat Permintaan Pembelian; b) Surat Permintaan Penawaran Harga; c) Surat Order Pembelian; d) Laporan Penerimaan Barang; e) Laporan Pengiriman Gudang; f) Memo Debit; g) Bukti Permintaan dan Pengeluaran Barang; h) Bukti Pengembalian Barang Gudang; i) Kartu Perhitungan Fisik; j) Daftar Hasil Perhitungan Fisik; k) Bukti Memorial. Menurut Mulyadi (2016:3), Catatan Akuntansi yang digunakan dalam sistem akuntansi persediaan adalah: a) Kartu Gudang; b) Kartu Barang; c) Kartu Persediaan; d) Kartu Hutang; e) Jurnal Umum [1].

Sistem dan Prosedur yang terkait dengan Sistem Akuntansi Persediaan adalah:

a) Prosedur pencatatan Produk Jadi; b) Prosedur Pencatatan Harga Pokok Produk Jadi yang Dijual; c) Prosedur Pencatatan Harga Pokok Produk Jadi yang Diterima Kembali dari Pembeli; d) Prosedur Pencatatan Harga Pokok Persediaan Produk Dalam Proses; e) Prosedur Pencatatan Harga Pokok Persediaan yang Dibeli; f) Prosedur Pencatatan Harga Pokok Persediaan yang Dikembalikan Kepada Pemasok; g) Prosedur Permintaan dan Pengeluaran Barang Gudang; h) Prosedur Pencatatan Tambahan Harga Pokok Persediaan karena Pengembalian Barang Gudang; i) Sistem Perhitungan Fisik Persediaan [1].

\subsection{Hasil Penelitian Relevan}

1. Penelitian terdahulu tentang sistem informasi akuntansi persediaan obatobatan terkomputerisasi yang efektif dan efisien pada perusahaan. Hasil penelitian menunjukkan masih terdapat beberapa kelemahan pada dua indikator terakhir, yaitu penggunaan komputer dalam sistem informasi akuntansi persediaan obat dan pengendalian penggunaan komputer dalam sistem informasi akuntansi persediaan obat. Atas kelemahan tersebut, diajukanlah beberapa saran perbaikan agar pengelolaan persediaan obat pada Rumah Sakit Umum Haji Surabaya menjadi lebih efektif dan efisien [4].

2. Penelitian terdahulu tentang analisis sistem informasi akuntansi atas pengadaan dan pengelolaan obat serta alat medis pada Rumah Sakit Islam Malang. Permasalahannya adalah kurang berperannya sistem informasi akuntansi atas pengadaan dan pengelolaan obat serta peralatan medis, dimana dalam kegiatan Rumat Sakit tersebut pihak manajemen kurang memperhatikan unsur-unsur sistem informasi akuntansi sehingga tidak dapat meningkatkan efektifitas dan efisiensi atas pengadaan 
dan pengelolaan obat serta peralatan medis [5].

3. Penelitian terdahulu tentang Evaluation of Inventory Accounting Information Systems at Dira Supermarket (Dira Shopping Center) Ambul. Hasil penelitian menunjukkan bahwa terdapat beberapa prosedur yang tidak sesuai dengan konsep dan teori. Hal ini dapat dilihat dari ketidaksesuaian antara teori dan praktek yang dijalankan, diantaranya Kartu Gudang, Kartu Barang Hilang dan Rusak, Daftar Kebutuhan Barang Yang Akan Dibeli, dan Surat Pesanan Yang Dikirimkan Ke Pemasok masih perlu ditingkatkan dengan mengacu pada prinsip pemisahan fungsi operasi, fungsi penyimpanan aktiva dan fungsi pencatatan, kurangnya beberapa dokumen dan catatan akuntansi, pelaksanaan penghitungan fisik persediaan yang kurang sesuai [6].

\subsection{Kerangka Berpikir}

Berikut merupakan kerangka berpikir pada penelitian ini :

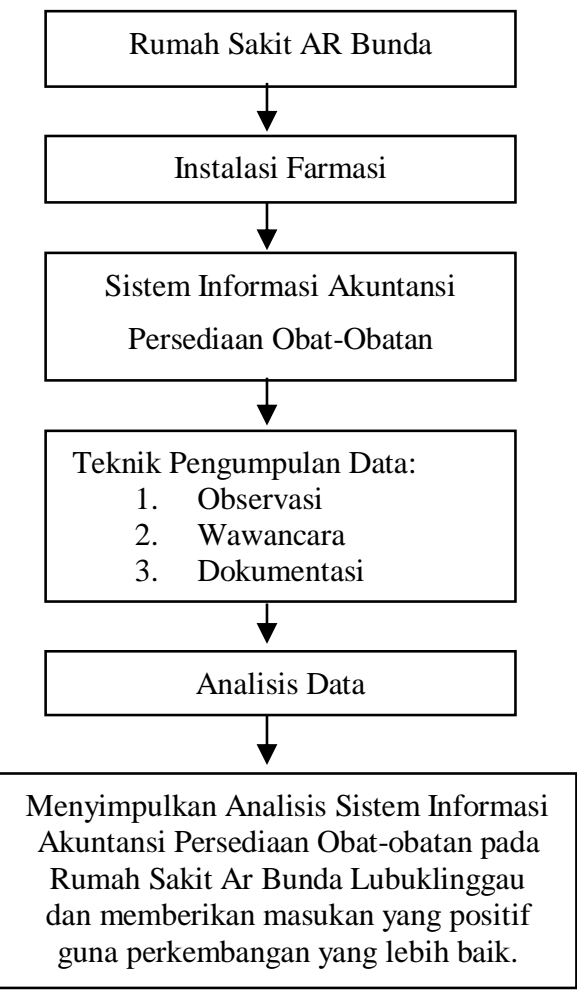

Gambar 1 Kerangka Berpikir

\section{METODOLOGI PENELITIAN}

\subsection{Jenis Penelitian}

Jenis penelitian yang dipakai adalah penelitian deskriptif kualitatif. Metode penelitian kualitatif adalah usaha untuk mendalami aspek pemahaman dalam suatu masalah. Semakin mendalam dan teliti data yang didapatkan, dapat diartikan semakin baik kualitas dari penelitian tersebut. Penelitian ini bersifat deskripsi, dimana data yang dikumpulkan lebih banyak huruf atau gambar dari pada angka. Penelitian ini bertujuan untuk mengetahui bagaimana sistem informasi akuntansi persediaan obatobatan pada Rumah Sakit AR Bunda Lubuklinggau.

\subsection{Tempat dan Waktu Penelitian}

Penelitian ini dilakukan di Rumah Sakit AR Bunda Lubuklinggau yang beralamatkan pada jalan Garuda No.245 RT.03 Kelurahan Bandung Kiri, Kecamatan Lubuklinggau Barat I, Kota Lubuklinggau, Sumatera Selatan. Waktu pelaksanaan penelitian dimulai dari bulan Januari 2020 sampai dengan bulan Agustus 2020.

\subsection{Data dan Sumber Data}

Data yang digunakan dalam penelitian ini adalah data primer dan data sekunder. Data primer dalam penelitian ini adalah hasil observasi dan wawancara dari bagian Farmasi, Administrasi serta Perencanaan dan pengadaan Rumah Sakit AR Bunda Lubuklinggau yang terkait dengan pengelolaan persediaan. Data sekunder dalam penelitian ini adalah gambaran umum, struktur organisasi dan job description, kebijakan akuntansi, prosedur persediaan obat dan dokumen-dokumen persediaan obat dari Rumah Sakit AR Bunda Lubuklinggau.

\subsection{Teknik Pengumpulan Data}

Data merupakan faktor yang sangat penting untuk mengetahui dan memperoleh gambaran tentang suatu persoalan atau 
keadaan, selain itu data dapat juga dijadikan sebagai dasar dalam membuat keputusan untuk memecahkan suatu persoalan. Datadata yang diperlukan dalam penelitian ini akan dikumpulkan melalui survey pendahuluan, observasi, kegiatan wawancara, serta studi literatur dengan jalan mengumpulkan teori-teori yang berhubungan dengan permasalahan sebagai landasan teori. Metode yang digunakan dalam pengumpulan data yaitu : 1) Wawancara 2) Dokumentasi 3) Observasi.

\section{HASIL DAN PEMBAHASAN}

\subsection{Hasil Penelitian}

Rumah Sakit AR Bunda Lubuklinggau diresmikan pada tanggal 19 September 2013. Rumah Sakit AR Bunda Lubuklinggau beroperasional berdasarkan Surat Keputusan Kepala Dinas Kesehatan Kota Lubuklinggau Nomor: 440/08/Kes/VIII/2013 tentang izin operasional sementara Rumah Sakit AR Bunda Lubuklinggau dan sekarang telah memiliki izin operasional tetap berdasarkan Surat Keputusan Walikota Lubuklinggau tentang izin operasional RS AR Bunda Lubuklinggau tanggal 29 oktober 2014 dengan Nomor: 287/KPTS/KES/2014.

Visi Rumah Sakit AR Bunda Lubuklinggau: Tercapainya Rumah Sakit yang Mandiri dengan Pelayanan yang Berkualitas, Profesional, Efektif dan Efisien.

Misi Rumah Sakit AR Bunda Lubuklinggau:

1. Meningkatkan Kualitas Sumber Daya Manusia Melalui Pembinaan, Pelatihan dan Pendidikan.

2. Meningkatkan Sarana dan Prasarana Kesehatan yang Modern dan Bermutu.

3. Menjadikan Pusat Rujukan Kesehatan Bagi Masyarakat Kota Lubuklinggau dan Sekitarnya.

4. Meningkatkan Kerjasama Pelayanan Kesehatan kepada semua pihak.

Dalam penelitian ini, peneliti data organisasi dan tata laksana dalam pengelolaan obat. Berikut ini merupakan organisasi dan tata laksana yang didapat peneliti:

1. Kepala Instalasi Farmasi

Kepala Instalasi Farmasi adalah seorang apoteker yang diberi tugas dan tanggung jawab dalam melaksanakan tugas mengkoordinir semua bagian farmasi di Rumah Sakit AR Bunda Lubuklinggau

2. Penanggung Jawab Pegelolaan Perbekalan Farmasi

Penanggung Jawab Pegelolaan Perbekalan Farmasi adalah seorang apoteker yang diberi tugas dan tanggung jawab untuk mengkoordinasi dan mengelola perbekalan farmasi di Rumah Sakit AR Bunda Lubuklinggau.

3. Penanggung Jawab Pelayanan Farmasi Klinik

Penanggung Jawab Pelayanan Farmasi Klinik adalah seorang apoteker yang diberi tanggung jawab dalam menyelenggarakan kegiatan pelayanan farmasi klinik di Rumah Sakit AR Bunda Lubuklinggau.

4. Penanggung Jawab Mutu

Penanggung Jawab Mutu adalah seorang apoteker yang diberi tugas dan tanggung jawab dalam pengendalian mutu pelayanan kefarmasian sesuai dengan rencana dan kegiatan monitoring seta evaluasi yang berkesinambungan di Rumah Sakit AR Bunda Lubuklinggau.

5. Staff Administrasi

Staff Administrasi adalah seorang non tenaga teknis kefarmasian yang diberi tugas dan tanggung jawab berkaitan dengan administrasi kegiatan pelayanan Instalasi Farmasi.

\subsection{Pembahasan}

Berikut fungsi yang Terkait dalam Sistem Informasi Akuntansi Persediaan adalah:

1. Fungsi Gudang

Fungsi gudang atau pada Rumah sakit AR bunda disebut juga dengan bagian 
gudang obat. Fungsi Gudang ditangani oleh penanggung jawab pengelolaan perbekalan farmasi.

2. Fungsi Pembelian

Fungsi pembelian untuk pembelian obatobatan ditangani oleh kepala Instalasi Farmasi Rumah Sakit AR Bunda dengan cara memesan obat-obatan yang diperlukan kepada pemasok. Fungsi ini bertanggungjawab membeli obat-obatan yang hampir habis kepada pemasok atau distributor obat.

3. Fungsi Pengiriman dan Penerimaan Barang

Fungsi Pengiriman dan Penerimaan Barang ditangani oleh penanggung jawab perbekalan farmasi. Fungsi ini bertanggungjawab dalam menerima barang yang masuk dan bertanggunjawab atas pengembalian barang kembali ke pemasok apabila terdapat retur pembelian, maupun pemeriksaan terhadap jenis, mutu dan kualitas barang yang diterima dari pemasok.

4. Fungsi Akuntansi

Fungsi Akuntansi ditangani oleh penanggung jawab pengelolaan perbekalan farmasi. Fungsi ini bertanggungjawab atas pencatatan transaksi, penyimpanan dokumen dan pembuatan laporan-laporan.

5. Fungsi Perhitungan Fisik Persediaan

Fungsi perhitungan fisik persediaan ditangani oleh penanggung jawab perbekalan farmasi. Fungsi ini bertanggungjawab dalam melaksanakan perhitungan fisik persediaan.

\section{Dokumen Terkait Sistem Informasi}

Akuntansi Persediaan:

1. Kartu Stock Barang, adalah nama-nama barang, jumlah yang dibutuhkan dan keterangan waktu habisnya barang yang dibutuhkan.

2. Surat Pesanan Obat, adalah dokumen yang dibuat yang berisi jenis obat dan jumlah yang dibutuhkan dan telah disetujui oleh Kepala Instalasi Farmasi. Surat ini berguna untuk mengajukan pesanan obat kepada rekanan atau distributor obat.

3. Berita Acara Penerimaan Obat, adalah dokumen yang dibuat sebagi bukti bahwa pesanan sediaan farmasi telah diterima oleh bagian gudang.

4. Formulir Permintaan Obat, adalah dokumen yang dibuat oleh unit farmasi untuk meminta obat-obatan pada bagian gudang.

5. Faktur Pembelian, adalah faktur yang diterima dari Distributor/Rekanan/Pemasok obatobatan untuk menunjukkan besarnya tagihan yang harus dibayarkan pihak Rumah Sakit AR Bunda.

6. Berita Acara Penghapusan Obat, adalah dokumen yang dibuat sebagai bukti bahwa telah dilaksanakannya penghapusan obat.

Catatan Akuntansi yang Digunakan dalam Sistem Informasi Akuntansi Persediaan. Catatan Akuntansi yang digunakan dalam Sistem Informasi Akuntansi Persediaan Obat-obatan pada Rumah Sakit AR Bunda Lubuklinggau adalah kartu gudang, kartu barang, kartu persediaan, kartu hutang dan jurnal umum.

Prosedur Perencanaan Pembelian Obat

1. Petugas farmasi/pihak Gudang melakukan pemeriksaan jumlah obat yang akan habis.

2. Sehari sebelum pemesanan perbekalan farmasi ke distributor farmasi, petugas farmasi melakukan pencetakan saran order.

3. Setelah dicetak, bukti pemesanan tersebut akan diperiksa dan ditandatangani oleh kepala Instalasi Farmasi. 
Prosedur Pengadaan Obat

1. Bagian Gudang membuat daftar sediaan farmasi yang telah kosong dan diserahkan kepada koordinator pengelola perbekalan farmasi secara kontinu per hari.

2. Koordinator Pengelola Perbekalan Farmasi membuat daftar pesanan sediaan farmasi dengan menentukan skala prioritas yang akan dilakukan pengadaan secara terencana (mingguan, bulanan, semester atau tahunan).

3. Menyerahkan daftar tersebut kepada kepala Instalasi Farmasi.

4. Surat Pesanan obat ditangani oleh Kepala Instalasi Farmasi kemudian diserahkan ke pedagang besar farmasi atau distributor yang menyediakan obat tersebut.

Prosedur Penyimpanan Obat-obatan

1. Barang diterima oleh bagian penerimaan dan pemeriksaan dengan menerima faktur dan obat yang dipesan, kemudian akan diperiksa kualitas dan kuantitas barang tersebut apakah sudah sesuai dengan yang tekah dipesan.

2. Barang akan diserahkan kepada bagian gudang untuk disimpan.

3. Bagian penerimaan gudang akan menerima barang dan menyimpan obat berdasarkan petunjuk penyimpanan dan waktu kadaluarsa pada masing-masing kemasan perbekalan farmasi agar dapat memudahkan dalam mendistribusikan obat.

4. Bagian gudang akan melakukan pencatatan barang atau menginputnya ke dalam kartu gudang.

\section{Prosedur Pendistribusian Obat-obatan}

1. Unit farmasi akan mengisi surat pengeluaran obat 3 rangkap yang akan diserahkan ke bagian gudang untuk mengeluarkan obat.
2. Bagian farmasi akan mengecek ketersediaan obat dan mengisi surat pengeluaran obat.

3. Bagian keuangan akan menandatangani surat pengeluaran obat.

4. Surat pengeluaran obat sudah diverifikasi oleh bagian gudang akan memberikan satu rangkap surat pengeluaran obat beserta obat ke unit farmasi.

Prosedur Perhitungan Fisik/Stock Opname

1. Komisi penerimaan tugas melakukan perhitungan fisik

2. Setelah perhitungan fisik dilakukan, maka komisi penerimaan tugas akan membuat dokumen hasil perhitungan fisik lalu diserahkan ke bagian gudang.

3. Bagian gudang menerima dokumen hasil perhitungan fisik. Selanjutnya bagian gudang akan melakukan penyesuaian catatan.

4. Setelah dilakukan pencocokan, bagian gudang akan menuliskan di buku pertanggungjawaban.

Prosedur Penghapusan Obat

1. Bagian gudang melakukan pengecekan obat-obatan yang telah rusak/kadaluarsa/cacat setiap bulannya kemudian petugas mencatat dalam formulir yang telah disediakan.

2. Formulir diterima di Instalasi Farmasi untuk selanjutnya diproses dan akan mengeluarkan formulir tersebut rangkap 2 (dua) yang akan diserahkan oleh Direktur untuk meminta persetujuan.

3. Setelah disetujui, formulir akan diberikan ke panitia tim penghapusan untuk dilakukan kegiatan penghapusan. Pengabusan obat dengan cara dibakar, dikubur, dilarutkan sesuai dengan jenis obat.

4. Kegiatan penghapusan obat selesai, tim penghapusan akan membuat berita acara penghapusan obat rangkap 2 (dua) yang akan diserhakan kepada Direktur sebagai 
tanda bukti telah dilakukannya

penghapusan obat.

Hasil Perbandingan Teori dan Praktek Sistem Informasi Akuntansi Persediaan pada Rumah Sakit AR Bunda Lubuklinggau

1. Fungsi/Bagian Terkait Sistem Informasi Akuntansi Persediaan

Fungsi yang digunakan dalam praktek sistem akuntansi persediaan pada Instalasi Farmasi Rumah Sakit AR Bunda sudah berjalan cukup baik, namun masih terdapat beberapa kekurangan seperti tidak adanya panitia bagian pembelian. Pembelian sediaan obat pada Rumah Sakit AR Bunda dilakukan oleh Kepala Instalasi Farmasi.

2. Dokumen/Formulir Terkait Sistem Informasi Akuntansi Persediaan

Dokumen yang digunakan dalam praktek sistem akuntansi persediaan pada Instalasi Farmasi Rumah Sakit AR Bunda ada yang belum sesuai dengan teori. Beberapa dokumen seperti bukti pengembalian barang ke gudang, laporan penerimaan barang dan laporan pengiriman barang diperlukan sebagai dokumen tambahan untuk mendukung pelaksanaan sistem akuntansi persediaan yang lebih baik.

3. Catatan Akuntansi yang digunakan dalam Sistem Informasi Akuntansi Persediaan

Catatan akuntansi yang diperlukan agar sesuai dengan teori sistem akuntansi persediaan antara lain: kartu gudang (kartu ini digunakan sebagai catatan untuk mencatat mutasi barang dan disimpan oleh bagian gudang), kartu persediaan (kartu ini diselenggarakan oleh fungsi akuntansi, digunakan sebagai catatan untuk mencatat kuantitas dan harga pokok serta berfungsi sebagai alat kontrol catatn kuantitas barang yang diselenggarakan oleh bagian gudang), kartu barang hilang/rusak (kartu ini digunakan untuk mencatat barang hilang/rusak).

4. Struktur Organisasi yang memisahkan tanggungjawab fungsional secara tegas Struktur organisasi merupakan kerangka pembagian tanggungjawab fungsional kepada unit-unit organisasi yang dibentuk untuk melaksanakan kegiatankegiatan pokok perusahaan. Dalam praktek pemisahan tanggungjawab fungsional yang diterapkan di Instalasi Farmasi Rumah Sakit AR Bunda, terdapat beberapa perangkapan fungsi. Perangkapan fungsi diperbolehkan selama resiko kerugian masih dapat dikendalikan. Contoh perangkapan fungsi pada Instalasi Farmasi Rumah Sakit AR Bunda yaitu Kepala Instalasi Farmasi yang merangkap sebaga bagian pemesanan dan pembeliaan sediaan obat pada distributor/ rekanan/ pemasok.

\section{KESIMPULAN}

Berdasarkan hasil penelitian yang telah dianalisis oleh peneliti, maka dapat ditarik kesimpulan yaitu Sistem Informasi Akuntansi pada Rumah Sakit AR Bunda terdiri dari 6 prosedur yaitu: 1) Prosedur Perencanaan Pembeliaan Obat; 2) Prosedur Pengadaan Obat; 3) Prosedur Penyimpanan Obat; 4) Prosedur Pendistribusiaan Obat; 5) Prosedur Perhitungan Fisik; 6) Prsoedur Penghapusan Obat.

Dari sistem dan prosedur akuntansi persediaan obat-obatan pada Rumah Sakit AR Bunda ditemukan perangkapan tugas yaitu Kepala Instalasi Farmasi yang melakukan pemesanan dan pembelian obatobatan pada pemasok/rekanan/ distributor obat. Sistem dan prosedur akuntansi persediaan obat-obatan pada Rumah Sakit AR Bunda masih memiliki kekurangan dalam beberapa dokumen dan catatan akuntansi serta tidak adanya fungsi penjualan yang dapat mendukung pelaksanaan sistem akuntansi persediaan. 


\section{SARAN}

Berdasarkan analisis yang telah dilakukan, maka peneliti memberikan saran yaitu Instalasi Farmasi Rumah Sakit AR Bunda Sebaiknya mengikutsertakan bagian keuangan dalam prosedur pengadaan obat. Bagian keuangan berperan untuk mengecek/memeriksa kondisi keuangan agar dapat memesan obat kepada distributor/rekanan/pemasok.

Selanjutnya agar pelaksanaan Sistem Informasi Akuntansi Persediaan Obat-obatan pada Rumah Sakit AR Bunda dapat berjalan lebih baik, maka disarankan Kepala Instalasi Farmasi tidak merangkap tugas. Instalasi Farmasi Rumah Sakit AR Bunda Lubuklinggau sebaiknya menambahkan beberapa dokumen dan catatan akuntansi yang diperlukan serta menambahkan fungsi penjualan pada fungsi terkait sistem akuntansi persediaan guna mendukung pelaksanaan sistem informasi akuntansi persediaan yang lebih baik.

\section{DAFTAR PUSTAKA}

[1] Mulyadi. 2019. Sistem Informasi Akuntansi Edisi Ke-empat Cetakan Kelima. Jakarta: Salemba Empat.

[2] Ikatan Akuntan Indonesia (IAI), 2017, Pernyataan Standar Akuntansi Keuangan (PSAK) No.14: Persediaan, Jakarta: IAI.

[3] Mulyadi. 2016. Sistem Informasi Akuntansi Edisi Ke-4. Jakarta: Salemba Empat.

[4] Krismiaji, 2015, Sistem Informasi Akuntansi, Unit Penerbit, Yogyakarta.

[5] Jogiyanto. 2014. Konsep Dasar Sistem Informasi. Konsep Dasar Sistem Informasi.
[6] Qutsiyah Inayatul, Halim Moh, and A Mirwan Rendy, "Evaluasi Sistem Informasi Akuntansi Persediaan Pada Dira Supermarket (Dira Shopping Center) Ambulu," Volume 3, Number 1, Tahun 2019, pp. 1-10. P-ISSN : 2614-6533 E-ISSN : 2549-6409. 